\title{
Multivariate Statistical Evaluation of Geochemical Data from Quartz Vein-Associated Gold Mineralisation at the Badukrom Prospect within the Tarkwaian Base*
}

\author{
${ }^{1}$ K.P. Osei, ${ }^{2}$ M. Affam, ${ }^{1}$ C. Kusi-Manu and ${ }^{1}$ D. T. Kwapong \\ ${ }^{1}$ AngloGoldAshanti Iduapriem Mines Ltd \\ ${ }^{2}$ University of Mines and Technology, Tarkwa
}

Osei, K. P., Affam, M, Kusi-Manu C. and Kwapong D. T, (2021), "Multivariate Statistical Evaluation of Geochemical Data from Quartz Vein-Associated Gold Mineralisation at the Badukrom Prospect within the Tarkwaian Base", Ghana Mining Journal, Vol. 21, No. 1, pp. 22-30.

\begin{abstract}
The Kawere conglomerate at the base of the Tarkwaian Group in the Iduapriem Mine appears to show good prospect for hydrothermal gold mineralisation evidenced by major structures mapped from magnetic and Airborne Electromagnetic (AEM) geophysical data. Detailed geological mapping and sampling at Badukrom target which lies within the Kawere rocks confirm the presence of multiple structures as well as quartz veins indicative of potential hydrothermal gold mineralisation. Follow up soil sampling conducted within the area revealed a strong anomalous trend from the southern portion. Two diamond drilled (DD) holes pushed to delineate the extent of the anomalous zones returned narrow veins of significant gold intersections. Twenty-five (25) samples of the Badukrom hydrothermal Au mineralisation intersects were sent for analysis to ascertain the optimum pathfinder element suite for the hydrothermal targets within the Iduapriem concession. A total of fifty-nine elements were analysed via ICP-MS and ICP-OES. Multivariate statistical evaluation was carried out on the results to understand the geochemical associations of $\mathrm{Au}$ and the other elements to aid future exploration programmes planned for the hydrothermal targets. Multivariate analysis of the geochemical data using Pearson product-moment of correlation suggests a stronger positive correlation of gold with Iron, Antimony, Sulphur, Chromium, Vanadium respectively. However, the Spearman Rank correlation data indicates that, the optimum pathfinder elements for hydrothermal Au are: $\mathrm{As}, \mathrm{Sb}$ and Te.
\end{abstract}

Keywords: Tarkwaian Base, Statistical Evaluation, Hydrothermal Mineralisation, Geochemical Data

\section{Introduction}

Two major gold mineralisation styles are known to occur in Ghana: (1) the hydrothermal mesothermal quartz vein gold mineralisation associated with shear zones and faults within the Birimian belts and (2) the paleoplacer deposits associated with the Tarkwaian Group (Kesse, 1985; Ridley, 2013). Economic gold mineralisation at Iduapriem has been known to occur within the conglomerates of the Banket Series of the Tarkwaian Group (Griffis et. al., 2002). Currently, exploitation of gold takes place in the Banket Series rocks which consist of individual beds of quartz pebbles and breccia conglomerates separated by quartzites. All gold mineralisation occurs within four specific zones namely, the A, B, C and D reefs with the highest grades, tonnage and geological continuity found in the $\mathrm{B}$ and $\mathrm{C}$ reefs.

However, evidenced by major structures mapped from magnetic and Airborne Electromagnetic (AEM) geophysical data, the Badukrum prospect shows good prospect for hydrothermal gold mineralisation within the Kawere conglomerate and at the contact between the Kawere and the Sefwi lithologies. Further works, which encompasses detailed geological mapping and sampling at the Badukrom prospect, confirmed the presence of multiple structures and quartz veins indicative of potential hydrothermal gold mineralisation. Two conceptual diamond holes drilled to delineate the extent of the anomalous zones returned narrow veins significant gold intersections (between 0.08 and $29.1 \mathrm{ppm}$ ). To ascertain the best likely pathfinder element suite for other hydrothermal targets within the Iduapriem lease, twenty-five samples were analysed via Inductively Coupled Plasma-Mass Spectrometry (ICP-MS) and Inductively Coupled Plasma Optical Emission Spectrometry (ICP-OES).

Usually in statistics, four major types of correlations could be employed to measure relationships between two variables. This includes Kendal, Pearson, Biserial and Spearman correlations. In this paper however, two of such multivariate statistical methods, Pearson and Spearman rank correlations coefficients were used. The most significant correlation coefficient using the geochemical data set was used to predict the best pathfinder element suite within the hydrothermal prospect at Badubrom prospect at Iduapriem Mine, and for prospecting similar concessions within the deposit.

This could guide exploration geologists with elemental analysis in addition to the selection of suitable pathfinder of gold for future mineral exploration programmes planned for the hydrothermal targets. Furthermore, this will provide information on the nature and mineral association of gold in similar prospects within the Tarkwaian. 


\subsection{Pearson and Spearman's Rank Correlation Coefficients}

The Spearman's rank correlation coefficient is a monotonic function or nonparametric measure which seeks to assess how well the relationship between two variables can be established. The major significance of Spearman correlation is that it shows direction of association between the independent variable $(X)$ and the dependent variable (Y). Under a given circumstance, if $Y$ tends to increase as $X$ also increases, then the correlation coefficient is said to be positive. The assumptions are that data must be at least ordinal and the score on one variable must be monotonically related to the variable in such that $(+1)$, zero and (-1) magnitudes indicate perfect, nil and negative associations respectively. The correlation function is given as:

$$
\rho=1-\frac{6 \sum d_{i}^{2}}{n\left(n^{2}-1\right)}
$$

where:

$\rho=$ Spearman's rank correlation coeffient

$d_{i}=$ difference between the two ranks of each observation

$n=$ number of observations

Pearson's product moment correlation coefficient is a measure of strength of a linear association between two variables. Correlation assumes that variables are normally distributed. The correlation function is given as:

$$
r=\frac{\sum\left(x_{1}-\bar{x}\right)\left(y_{1}-\bar{y}\right)}{\sqrt{\sum\left(x_{i}-\bar{x}\right)^{2}} \sum\left(y_{i}-\bar{y}\right)^{2}}
$$

where

$r=$ Pearson correlation coefficient

$x_{i}=$ Values of the $x$-variable

$\bar{x}=$ mean of the values of the $x$ variable

$y_{1=}$ value of the $y$-variable

$\bar{y}=$ Values of the $y$-variable

If the magnitude of correlation coefficient falls between 0.5 and 0.7 , it indicates Moderate correlation while if value falls between 0.3 and 0.5 it indicates low correlation It is worth noting that the Pearson product-moment coefficient of linear correlation assumes that variables are normally distributed and have linear relationships. However, the Spearman rank correlation does not require normal distribution of variables. It rather assumes random variables thereby making it more efficient for analysing major or trace element data.

\subsection{The Geology of Iduapriem Concession}

The Iduapriem concession is located within the Tarkwaian Group of rocks that form part of the West Africa Craton, which is covered to a large extent by metavolcanics and metasediments of the Birimian Supergroup (Fig. 1) (Griffis et. al., 2002).

The entire Tarkwaian Group has been folded into a broad syncline which is locally referred to as the Tarkwa Syncline (Fig. 3) (Anon, 2005).

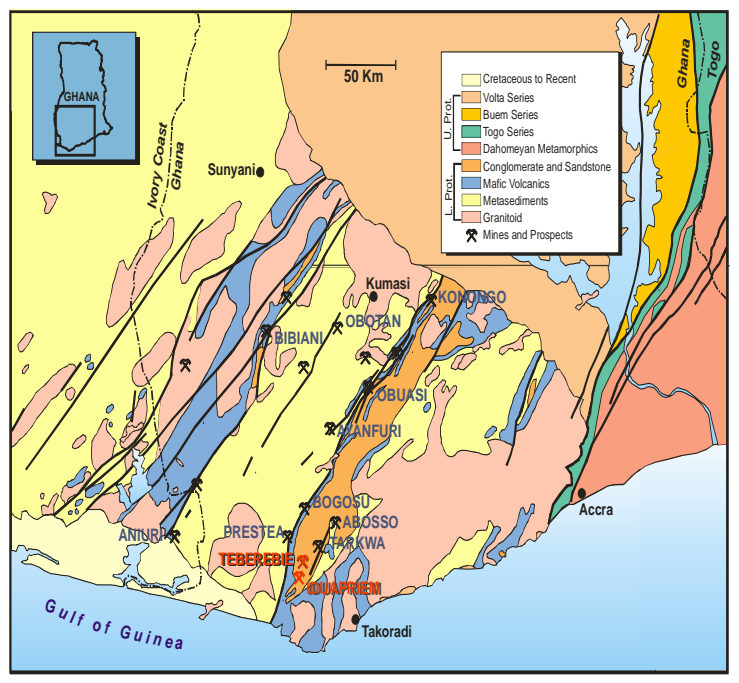

Fig. 1 Geology Map of South-West Ghana

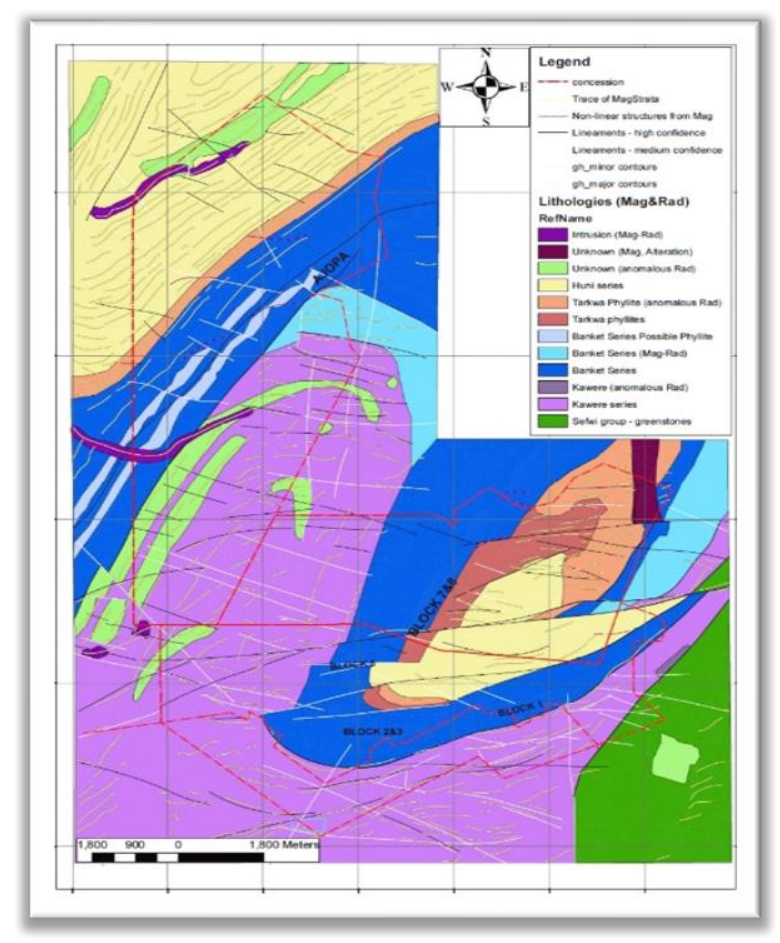

Fig. 2 Geological Map of the Iduapriem

The Iduapriem concession is located along the south-western margin of the Tarkwa syncline (Fig. 3) The main lithologies in Iduapriem block include the Huni Series (phyllites, conglomerates, sandstones), Tarkwa Phyllites, Banket Series (conglomerates, sandstones), Kawere Series (sandstones, conglomerates) and basal Sefwi Group (volcaniclastics and granitoids) (Fig. 3). 


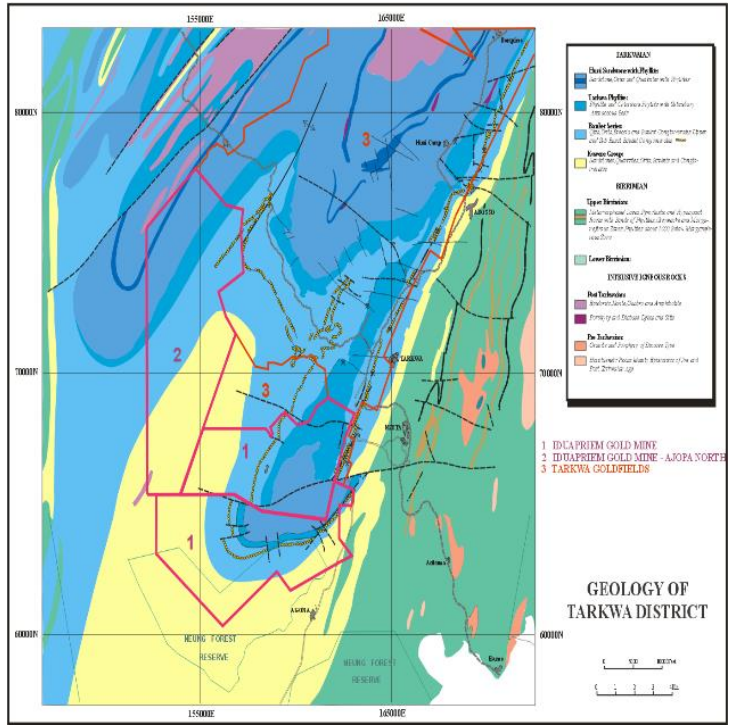

Fig. 3 Geological Map of the Tarkwa Basin

Gold mineralisation is confined to the Banket Reef Zone (BRZ), which comprises a sequence of individual beds of quartz pebble conglomerate, breccia conglomerate, quartzite and grit. The outcropping Banket Series in the mine lease area forms prominent curved ridges that extend southwards from Tarkwa, westwards through Iduapriem and northwards towards Teberebie. The deposit consists of eight blocks (i.e. Blocks 1-8) (Anon., 2005).

At Blocks $7 \& 8$ (Teberebie deposit), the western limb of the syncline extends over 4 kilometres on the property, with the eastern limb reaching the surface (outcropping) just beyond the eastern boundary of the concession. The western and the eastern limbs outcrop about 4 kilometres apart with the mineralised horizons buried some 400 metres below the surface at the centre of the syncline (Anon., 2005),

The Ajopa deposit (Block 6), comprise of a series of north-east south-west (NE-SW) trending ridges with dips generally between 50 to $60^{\circ} \mathrm{W}$. The gold is fine-grained, particulate and free milling (i.e. not locked up with quartz or iron oxides). Mineralogical studies indicate that the grain size of native gold particles ranges between $2 \mu \mathrm{m}$ and $500 \mu \mathrm{m}$ and averages $130 \mu \mathrm{m}$. Sulphide mineralisation is present only at trace levels and is not associated with the gold. Haematite mineralisation is often extremely well developed on cross bed fore sets. The conglomerates often show strong haematite mineralisation in the matrix with rare visible gold grains.

\subsection{The Badukrom Project}

The hydrothermal target at Badukrom, a locality within the Iduapriem concession. sits within the
Kawere conglomerates at the base of the Tarkwaian Group (Fig. 4). Mineralisation is associated with pyrite+carbonate+tourmaline with primary magnetite seemingly stable (Fig 5). Geochemical soil anomaly at the Badukrom prospect occur parallel to the regional scale anticline with strong sulphidation in country rock sandstone.

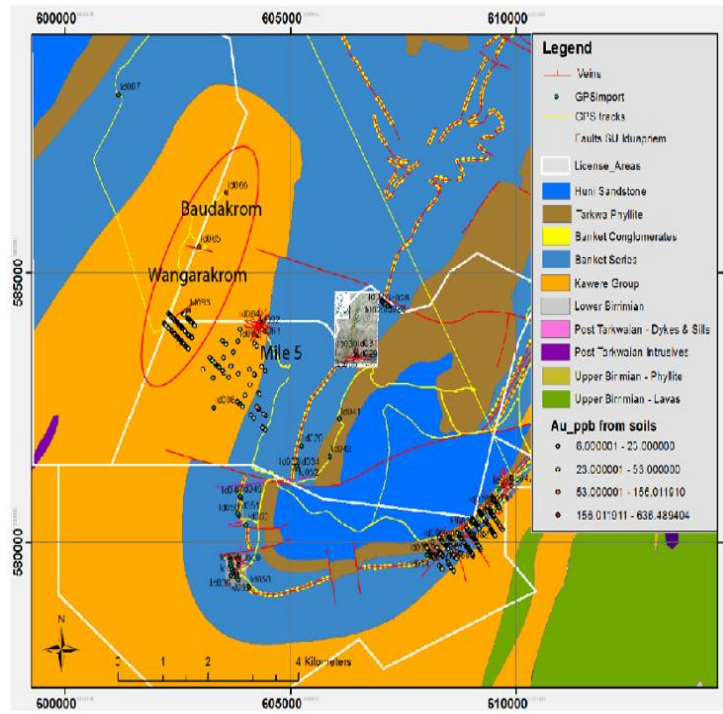

Fig. 4 Map of the Iduapriem Block Showing the Badukrom Prospect

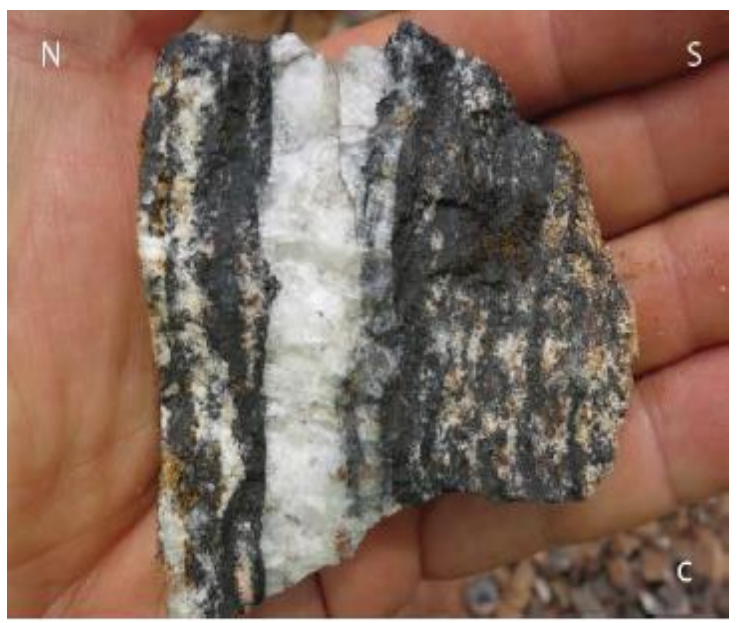

Fig. 5 Badukrom Quartz Vein-Related Mineralisation

\section{Resources and Methods Used}

\subsection{Data Description}

The samples utilised in this study were selected from two conceptual DD holes (BD001 and BD002) drilled at the Badukrom prospect to delineate the extent of the quartz vein mineralisation. Twenty-five (25) samples of hydrothermal quartz veining were selected for multi-element analysis. The multielements were analysed at SGS South Africa Pty Ltd in Johannesburg by four-acid digestion and analysis 
via ICP-OES (Al, Ba, Ca, Cr, Cu, Fe, K, Li, Mg, Mn, $\mathrm{Na}, \mathrm{P}, \mathrm{S}, \mathrm{Sr}, \mathrm{Ti}, \mathrm{V}, \mathrm{Zn}$ and $\mathrm{Zr}$ ) and ICP-MS (Ag, As, $\mathrm{Be}, \mathrm{Bi}, \mathrm{Cd}, \mathrm{Ce}, \mathrm{Co}, \mathrm{Cs}$, Dy, Er, Eu, Ga, Gd, Ge, Hf, $\mathrm{Ho}, \mathrm{In}, \mathrm{La}, \mathrm{Lu}, \mathrm{Mo}, \mathrm{Nb}, \mathrm{Nd}, \mathrm{Ni}, \mathrm{Pb}, \mathrm{Pr}, \mathrm{Rb}, \mathrm{Sb}, \mathrm{Sc}$, Se, Sm, Sn, Ta, Tb, Te, Th, Tl, Tm, U, W, Y and $\mathrm{Yb})$. Gold was assayed by SGS in Tarkwa.

The four-acid digestion has a very effective dissolution procedure for a large number of mineral species and is best for this work. The analytical technique involved the use of a combination of $\mathrm{HNO}_{3}$ (nitric acid), $\mathrm{HF}$ (hydrofluoric acid), $\mathrm{HClO}_{4}$ (perchloric acid) and $\mathrm{HCl}$ (hydrochloric acid) to attain a near-total digestion. ICP-OES and ICP-MS finish were utilised because this geoanalytical instrumentation techniques yield many elements concurrently and are universally recognised in the mineral exploration industry as a faster and efficient means for trace element analysis ( Hu, 2014 and Finch et al., 2018).

\subsection{Data Processing and Analysis}

Multivariate statistical analysis which involves two or more variables considered simultaneously was used to analyse the geochemical data. In addition, graphical analysis involving scatter plots between gold and other elements were generated to measure the degree of interrelation between the variables. The correlation coefficient $(r)$ which measures the degree of interrelations between gold and other elements was computed and displayed as a matrix via both Pearson product-moment coefficient of linear correlation and the Spearman rank correlation.

\section{Results and Discussion}

\subsection{Descriptive Statistics for Au}

The descriptive statistic for Au is shown in Table 1 The result displays quite an interesting recovery from the least expected Badukrom prospect. Using the sample size of 25, it implies according to Hair et al., (2013) that since $R^{2}$ is approximated above 39 , it is deemed statistically significant for the simple linear regression analysis used in this study. The mean $\mathrm{Au}$ value for the sample is $2.82 \mathrm{ppm}$ with grades varying from $0.08-29.1 \mathrm{ppm}$. Most of the samples recorded more than $1.0 \mathrm{ppm}$ rising up to $29.02 \mathrm{ppm}$, although significant proportion fell below cut-off grade of $0.5 \mathrm{ppm}$.

\subsection{Statistical Analysis}

The correlation coefficients for both the Pearson product-moment and Spearman rank were computed to determine the degree of association of gold with each of the 59 elements. Results of the Pearson correlation matrix revealed a stronger positive correlation between Gold and Iron, Antimony,
Sulphur, Chromium, Vanadium, Copper, Silver, Selenium and Cobalt (see Tables $2 \& 3$ ). The other elements showed moderate to poor association with $\mathrm{Au}$ mineralisation. The scatter plots for elements with strong association to gold are illustrated below:

Table 1 Au Descriptive Statistics

\begin{tabular}{|l|c|}
\hline \multicolumn{2}{|c|}{ Au (PPM) } \\
\hline Mean & 2.82 \\
\hline Standard Error & 1.15 \\
\hline Median & 0.86 \\
\hline Mode & 0.64 \\
\hline Standard Deviation & 5.77 \\
\hline Sample Variance & 33.31 \\
\hline Kurtosis & 19.65 \\
\hline Skewness & 4.27 \\
\hline Range & 29.02 \\
\hline Minimum & 0.08 \\
\hline Maximum & 29.1 \\
\hline Sum & 70.52 \\
\hline Count & 25 \\
\hline Largest(1) & 29.1 \\
\hline Smallest(1) & 0.08 \\
\hline Confidence Level (95.0\%) & 2.38 \\
\hline
\end{tabular}

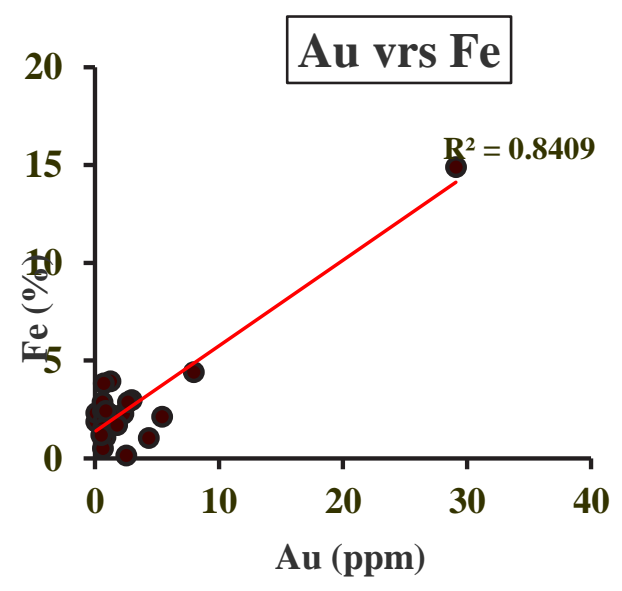

Fig. 6 Plot of Au versus Fe

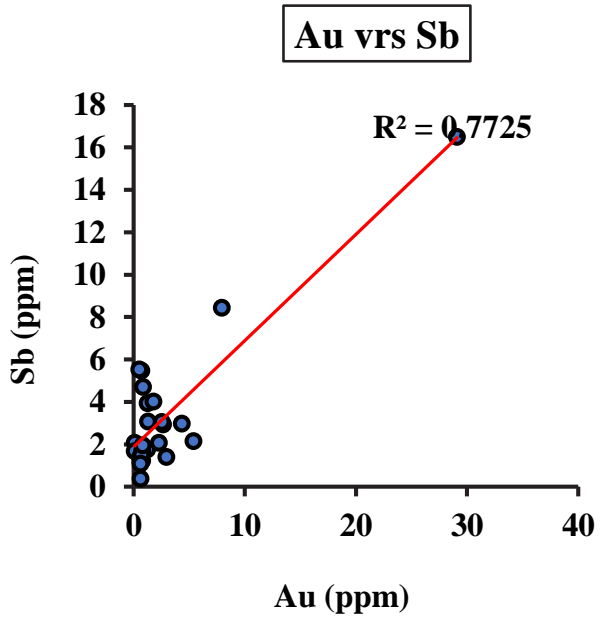

Fig. 7 Plot of Au versus Sb 


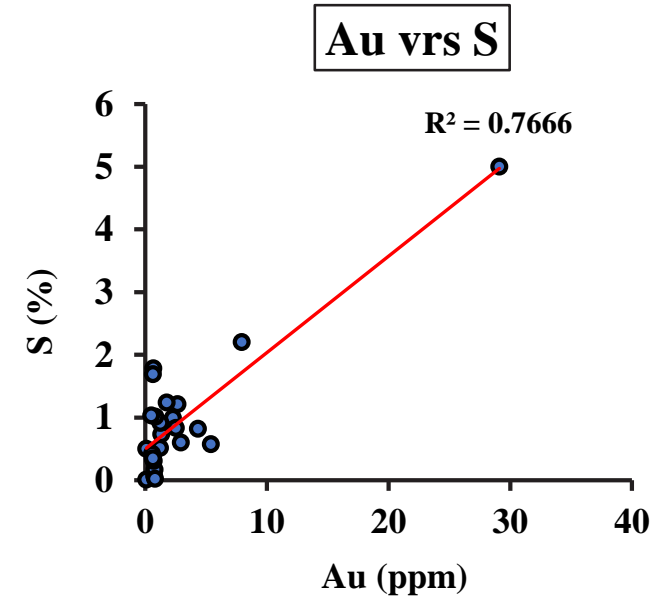

Fig. 8 Plot of Au versus S

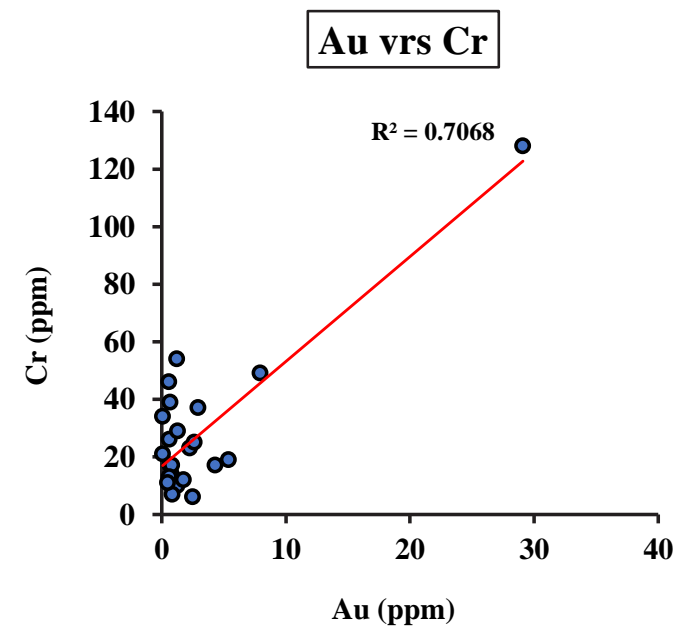

Fig. 9 Plot of Au versus $\mathrm{Cr}$

As shown on the above scatter plots, Fe has the strongest association with Au with a coefficient (R) of 0.92 (Fig. 6). Sb and $\mathrm{S}$ show a correlation coefficient (R) of 0.88 (Figs, 7 \& 8) whilst $\mathrm{Cr}$ gives an R of 0.84 with Au (Fig. 9).

On the other hand, Spearman Rank correlation coefficients (see Tables $2 \& 4$ ) indicated that $\mathrm{Au}$ present moderate correlation with $\mathrm{Ag}(\mathrm{R}=0.558)$, As ( $R=0.504), \mathrm{Sb}(\mathrm{R}=0.474)$; (Fig. 10) $\mathrm{Te}(\mathrm{r}=0.453)$, and weak correlation with $\mathrm{S}(\mathrm{r}=0.395), \mathrm{Se}(\mathrm{r}=0.391)$ and $\mathrm{U}(\mathrm{r}=0.336)$.

\subsection{Discussions}

A comparison of the results of the Pearson productmoment coefficient and the Spearman Rank Correlation coefficients shows significant differences in the degree of interrelations between $\mathrm{Au}$ and the other elements. The data shows that the minimum $R^{2}$ is considered statistically significant considering the powers obtained (Table 2). Gold shows a stronger correlation with Iron, Antimony,
Sulphur, Chromium, Vanadium based on the data analysis with the Pearson correlation matrix (Table 3), whilst it shows moderate correlation with Silver, Arsenic, Antimony and Tellurium and weak correlation with Sulphur. The strength of correlation ranges from strong to moderate for the Pearson whilst that of the Spearman Rank ranges from moderate to weak for the likely pathfinder elements (Table 2). Despite, seemingly strong to moderate Pearson correlation which suggest linear relationship between the variables, the erratic signature of $\mathrm{Au}$ within the deposit does not fully support the theoretical assumption.

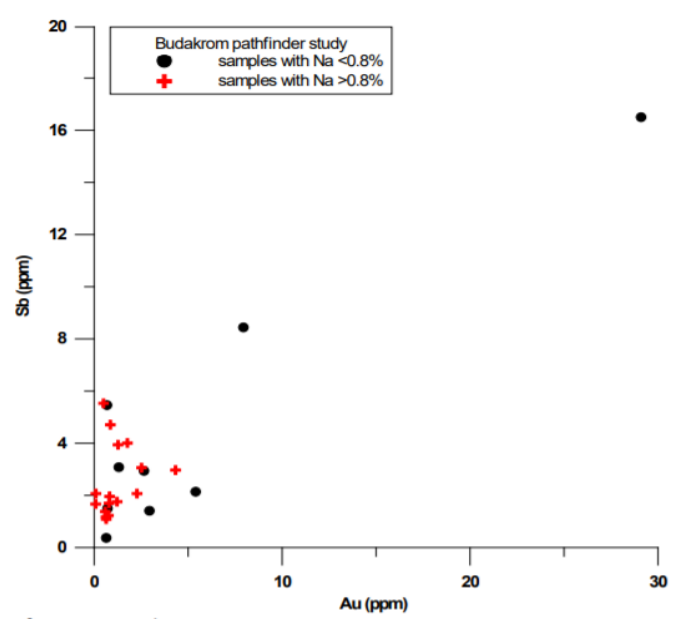

Fig. 10 Spearman Rank Correlation Plot of Au versus $\mathrm{Sb}$

Table 2 Pearson and Spearman Rank Correlation Coefficients for likely Pathfinder Elements at Badukrom

\begin{tabular}{|l|c|c|}
\hline & Pearson & Spearman Rank \\
\hline Element & $\mathrm{Au}(\mathrm{PPM})$ & $\mathrm{Au}(\mathrm{PPM})$ \\
\hline $\mathrm{Au}(\mathrm{PPM})$ & 1 & 1.00 \\
\hline $\mathrm{Fe} \%$ & 0.92 & 0.23 \\
\hline $\mathrm{Sb}(\mathrm{PPM})$ & 0.88 & 0.47 \\
\hline $\mathrm{S} \%$ & 0.88 & 0.40 \\
\hline $\mathrm{Cr}(\mathrm{PPM})$ & 0.84 & 0.23 \\
\hline $\mathrm{V}(\mathrm{PPM})$ & 0.84 & 0.31 \\
\hline $\mathrm{Cu}(\mathrm{PPM})$ & 0.77 & -0.20 \\
\hline $\mathrm{Ag}(\mathrm{PPM})$ & 0.73 & 0.56 \\
\hline $\mathrm{Se}(\mathrm{PPM})$ & 0.73 & 0.39 \\
\hline $\mathrm{Co}(\mathrm{PPM})$ & 0.72 & 0.29 \\
\hline $\mathrm{Ni}(\mathrm{PPM})$ & 0.64 & 0.30 \\
\hline $\mathrm{Ti} \%$ & 0.61 & -0.12 \\
\hline $\mathrm{As}(\mathrm{PPM})$ & 0.30 & 0.50 \\
\hline $\mathrm{Te}(\mathrm{PPM})$ & 0.26 & 0.45 \\
\hline
\end{tabular}

Hence, based on the Spearman rank data (Table 2), the most useful elements including as (up to $>1 \%$ ), $\mathrm{Sb}$ (0.37-16.5 ppm) and Te (0.19-32 ppm), and Ag assays which fell below $1 \mathrm{ppm}$ present much probabilistic elemental pathfinder tracing. The 
ranges for other potential pathfinder elements are somewhat inconsistent: (Se <2-7; S 0.01->5; and U 0-14-0.27).

Arsenic is also relatively strongly correlated with $\mathrm{S}$ $(\mathrm{r}=0.735), \mathrm{Sb} \quad(\mathrm{r}=0.823), \mathrm{Se}(\mathrm{r}=0.771)$ and $\mathrm{Te}$ $(\mathrm{r}=0.84)$ (see Table 4).

The Zr vs. Ti diagram (Fig. 11) tries to interpret the possible hydrothermal setting of the felsic mineralogy and melting proportions according to Hanson (1980),

There appears to be two group of samples: those with $\mathrm{Na}<0.8 \%$ and with elevated $\mathrm{K}$, and those with $\mathrm{Na}>0.8 \%$ and lower concentrations of $\mathrm{K}$. This does not appear to be related to difference in rock type but may reflect differences in mineralogy of the hydrothermal alteration. A positive correlation of the minerals on a plot of $\mathrm{Zr}$ vs. $\mathrm{Ti}$, therefore, indicates a simultaneous role of assimilation and fractional crystallization.

It depicts the possibility that the range in chemical composition within the deposit might be a result of varying degrees of partial melting of a parent material or fractional crystallization of a differentiated magma as has been suggested by work of Lightfoot et al. (1987) in other deposits of similar tectonics. This however, could be properly could be resolved by spectral analysis, XRD or petrography.

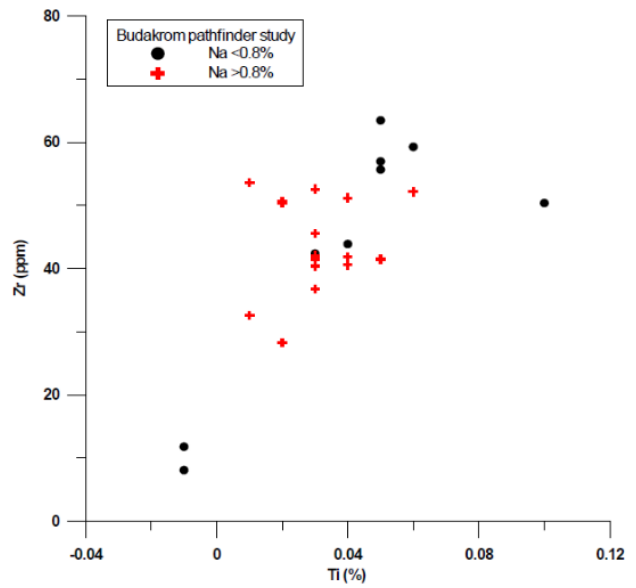

Fig. 11 Plot of Ti versus $\mathrm{Zr}$

\section{Conclusions and Recommendations}

\subsection{Conclusion}

Analysis of the geochemical data using Pearson product-moment reveals that $\mathrm{Au}$ has a stronger positive linear relationship with Iron, Antimony, Sulphur, Chromium, Vanadium, Copper, Silver, Selenium and Cobalt. It shows a stronger correlation with Iron and Sulphur, which suggests that it occurs either as inclusions or substitutions within pyrite. However, this practically does not support seemingly erratic hydrothermal deposit at Badukrom. On the other hand, Spearman's ranking which is monotonically related and showing moderate to poor correlation with $\mathrm{Au}$ mineralization, appears more realistic.

Spearman rank assumes random variables and appears more efficient for trace element analysis and hence best technique for indicator tracing for deposit of this nature

The Zr vs. Ti diagram depicts the strong possibility of hydrothermal setting of felsic to mafic mineralogy and varying melting proportions.

Therefore, the optimum pathfinder elements for hydrothermal $\mathrm{Au}$ tracing within the Badukrom prospect include: $\mathrm{As}, \mathrm{Sb}$ and $\mathrm{Te}$.

\subsection{Recommendation}

It is recommended that more detailed drilling programme is carried out to further probe the deposit.

\section{Acknowledgement}

The authors are grateful to the management of Anglogold Ashanti Iduapriem Mine Ltd, from where data for this research was sourced. We appreciate effort made by everyone.

\section{References}

Anon. (2005), "Iduapriem 2006 Business Plan Geology Report", Unpublished Annual Report, Iduapriem, $49 \mathrm{pp}$.

Finch, C., Roldan, R., Walsh, L., Kelly, J. and Amor, S. (2018), "Analytical methods for chemical analysis of geological materials", Government of Newfoundland and Labrador, Department of Natural Resources, Geological Survey, Open File NFLD/3316, 67 pp.

Griffis, R.J., Barning, K., Agezo, F.L., Akosah, F.K. (2002), "Gold Deposits of Ghana", Minerals Commission, Accra, Ghana. 432 pp.

Hair, J., Black, W., Babin, B. and Anderson, R. (2013), Multivariate Data Analysis, $7^{\text {th }}$ edition, Pearson, pp. 89-231.

Hanson, G.N., (1980), "Rare earth elements in petrogenetic studies of igneous rocks", Annal Review of Earth and Planetary Sciences, Vol 8, pp. 371-406.

$\mathrm{Hu}$, Zhaochu. (2014), "Sample digestion methods. Reference Module in Earth Systems and Environmental Sciences", Treatise on Geochemistry Sec. Ed., Vol. 15, pp 87-109.

Kesse, G. O. (1985), The Mineral and Rock Resources of Ghana, A. A. Balkema Publishers, Rotterdam, 610 pp. 


\section{Table 3 Pearson Rank Correlation Matrix}

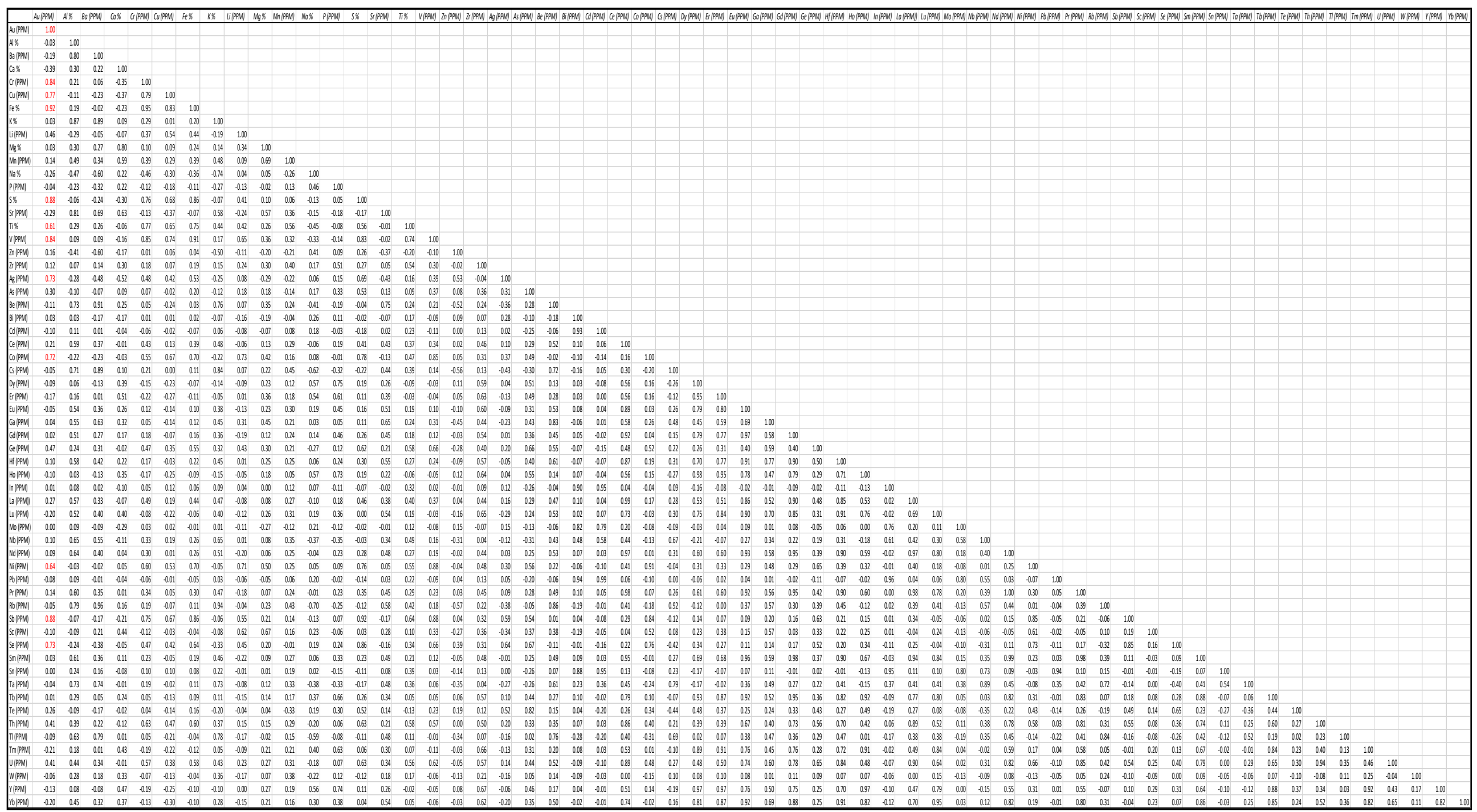




\section{Table 4 Spearman Rank Correlation Coefficients}

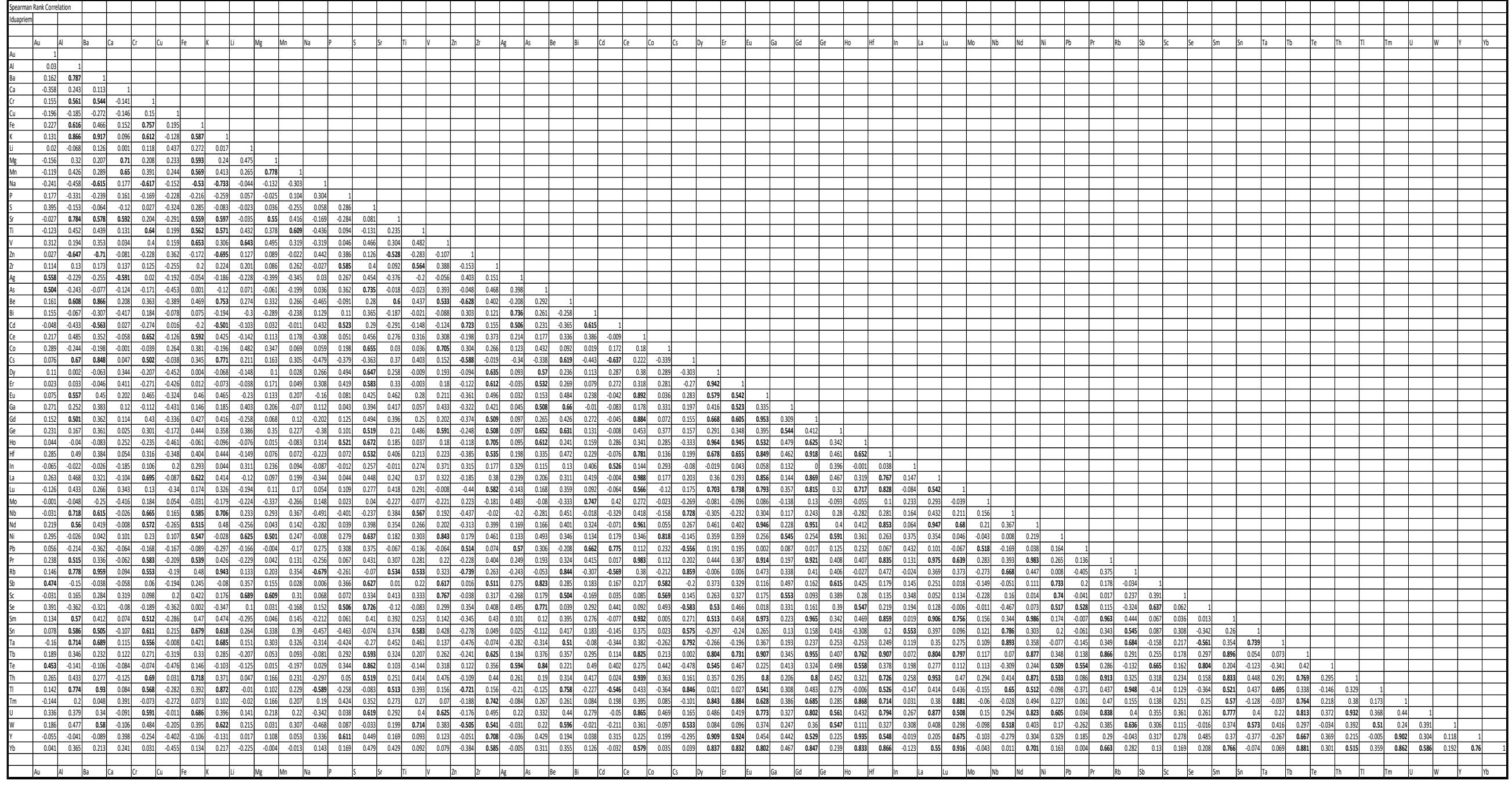

ब.ง Vol. 21, No.1, June., 2021 
Lightfoot, P.C., Hawkesworth, C.J., Sethna, S.F., 1987. Petrogenesis of rhyolites and trachytes from the Deccan Trap: $\mathrm{Sr}, \mathrm{Nd}$, and $\mathrm{Pb}$ isotope and trace element evidence. Contributions to Mineralogy and Petrology, Vol 95, pp. $44-54$.

Ridley, J. (2013). Frontmatter. In Ore Deposit Geology Cambridge: Cambridge University Press, pp. 1-4.

\section{Authors}

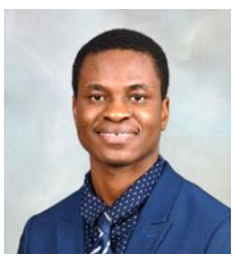

Kofi Poku Osei is a Geologist at the Geology Department at Iduapriem Mine, Tarkwa. He holds BSc degree in Geological Engineering from the University of Mines and Technology (UMaT), Tarkwa and an MSc in Mining Geology and Mineral Exploration from Western Australia School of Mines, Curtin University, Australia. He is a Member of the Australasian Institute of Mining and Metallurgy, Australian Institute of Geoscientist and a Graduate member of the Ghana Institution of Engineers.

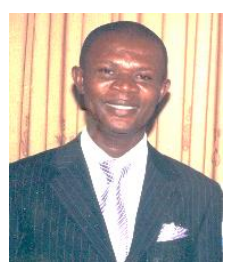

Michael Affam is currently an Associate Professor at the Department of Geological Engineering, University of Mines and Technology (UMaT), Tarkwa, Ghana. He holds PhD degree in Geological Engineering (Geotechnical option) from UMaT/ Queens University, Canada, MSc and BSc degrees from Kwame Nkrumah University of Science and Technology, Kumasi. Ghana. His specialty is in advances in geomechanics, foundation design and exploration techniques.

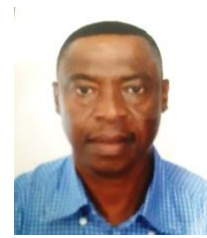

Charles Kusi-Manu, is currently the Senior Manager, Geology Department at Iduapriem Mine. He holds MSc (Fin) and MBA (Mgmt.) all in Leeds Beckett Uni, UK. He is also a Chartered Professional Member of the Australasian Institute of Mining and Metallurgy, MAuSIMM (CP). He has over 30 years' practical experience in mining geology, exploration (brown and green fields), mineral resource evaluation, business planning and consulting. He is well-versed in the mineral resource industry and has held various management and supervisory roles during this period.

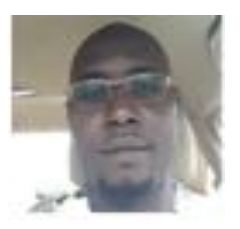

Divine Tony Kwapong is currently the Chief Exploration Geologist for Anglogold Ashanti Iduapriem Mine Ltd. He holds a BSc degree (Hons.) in Geology from the University of Ghana. He has over 10 years' experience in Brownfields Exploration. He has worked in a couples of companies within and outside Ghana, including Golden Star Resources and Guyana Shield for Manganese Exploration. 